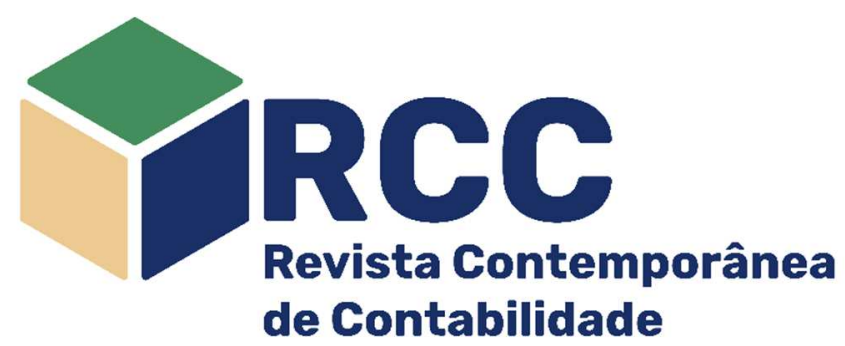

\title{
Adoção do valor justo para ativos não financeiros: evidências da Alemanha, Brasil e Reino Unido
}

\author{
Adoption of fair value for non-financial assets: evidence from Germany, Brazil and the United \\ Kingdom
}

\author{
Adopción del valor justo para los activos no financieros: evidencias de Alemania, Brasil y Reino \\ Unido
}

Aline Fernandes Pinto* Mestre em Contabilidade (UFU), Uberlândia/MG Brasil fernandes.aline63@yahoo.com.br https://orcid.org/0000-0002-6466-5226 (i)
Sirlei Lemes

Doutora em Controladoria e Contabilidade (USP) Professora do Programa de Pós-Graduação em Ciências Contábeis (UFU), Uberlândia/MG, Brasil sirlemes@uol.com.br https://orcid.org/0000-0003-3334-4240 (1)

Neirilaine Silva de Almeida Doutora em Contabilidade (UFU) Professora da Faculdade de Ciências Contábeis (UFU), Uberlândia/MG, Brasil neirilaine@ufu.br http://orcid.org/0000-0001-5687-9833 (10)

Endereco do contato principal para correspondência* Avenida João Naves de Ávila, 2121 - Campus Santa Mônica - Bloco F, CEP: 38.408-100 - Uberlândia/MG, Brasil

\section{Resumo}

O presente estudo teve o objetivo de identificar os fatores que se associam com a escolha do método para a mensuração de ativos não financeiros. Para tanto, selecionou-se uma amostra com 150 companhias da Alemanha, Brasil e Reino Unido. O período amostral refere-se ao ano de adoção das IFRS em cada país, sendo 2005 para Alemanha e Reino Unido e 2010 para o Brasil. A associação entre as escolhas contábeis na mensuração dos ativos não financeiros e o país, o porte, a rentabilidade e o nível de endividamento foi verificada por meio de teste Qui-quadrado. Os resultados indicam que o país, o tamanho e o nível de endividamento apresentam associação com o método escolhido de mensuração dos ativos não financeiros, o que não foi evidenciado em relação à rentabilidade. Adicionalmente, os resultados suportam a suposição de preferência das companhias da amostra pelo uso do custo histórico.

Palavras-chave: Escolhas contábeis; Valor justo; Ativo não financeiros; Alemanha; Brasil; Reino Unido

\section{Abstract}

The present study aimed to identify the factors that are associated with the choice of method for the measurement of non-financial assets. To do so, a sample was selected with 150 companies from Germany, Brazil and the United Kingdom. The sample period refers to the year of adoption of IFRS in each country, being 2005 for Germany and the United Kingdom and 2010 for Brazil. The association between the accounting choices in the measurement of the non-financial assets and the country, size, profitability and level of indebtedness was verified by means of Chi-square test. The results indicate that the country, size and level of indebtedness are associated with the chosen method of measurement of non-financial assets, which was not evidenced in relation to profitability. Additionally, the results support the assumption of preference of the sample companies by the use of historical cost.

Keywords: Accounting choices; Fair value; Non-financial assets; Germany; Brazil; United Kingdom

\section{Resumen}

El presente estudio tuvo el objetivo de identificar los factores que se asocian con la elección del método para la medición de activos no financieros. Para ello, se seleccionó una muestra con 150 compañías de Alemania, 
Brasil y el Reino Unido. El período muestral se refiere al año de adopción de las NIIF en cada país, siendo 2005 para Alemania y Reino Unido y 2010 para Brasil. La asociación entre las opciones contables en la medición de los activos no financieros y el país, tamaño, rentabilidad y el nivel de endeudamiento se verificó por medio de la prueba Chi-cuadrado. Los resultados indican que país, tamaño y nivel de endeudamiento presentan asociación con el método elegido de medición de los activos no financieros, lo que no se evidenció en relación con la rentabilidad. Adicionalmente, los resultados apuntan la preferencia de las compañías de la muestra por el uso del costo histórico.

Palavras chave: Opciones Contables; Valor justo; Activos no financieros; Alemania; Brasil; Reino Unido

\section{Introdução}

A escolha entre o valor justo e o custo histórico ainda é tema controverso na contabilidade. Se por um lado o uso do valor justo na mensuração dos ativos pode aumentar a relevância e a transparência das informações financeiras, por outro, as estimativas requeridas nesse processo podem possibilitar a existência de manipulações e, consequentemente, afetar a confiabilidade das informações financeiras (DIETRICH; HARRIS; MULLER, 2001; MCDONOUGH; SHAKESPEARE, 2015). Para Barth (2013), o valor justo tem a capacidade de auxiliar a obtenção da comparabilidade, uma vez que permite que as semelhanças e diferenças econômicas entre os ativos estejam representadas fidedignamente nas demonstrações financeiras. Entretanto, a autora enfatiza a preocupação com a possível existência de manipulação no valor justo estimado pelos gestores. Isa (2014) destaca que o valor justo pode ser empregado com o intuito de apresentar menores resultados operacionais, uma vez que o método tende a acarretar maiores despesas de depreciação relacionadas aos ativos não circulantes. Por outro lado, o custo histórico permite que os gestores evidenciem um crescimento no resultado organizacional, considerando que a depreciação é calculada com base no custo histórico que, em condições econômicas normais, tende a ser inferior ao valor justo (ISA, 2014).

Outro ponto conflitante que permeia a adoção do valor justo é que, de fato, as International Financial Reporting Standards (IFRS) possibilitam que os gestores escolham a prática contábil que melhor representa a situação econômica e financeira das entidades em que atuam. Assim, a adoção das IFRS tem o potencial para aumentar a comparabilidade das informações extraídas dos relatórios contábeis (ZEFF, 2007). Contudo, também é preciso considerar que as diferenças existentes na cultura contábil, empresarial e financeira, bem como os aspectos relacionados à auditoria e à regulação de cada país podem dificultar o alcance da comparabilidade das informações financeiras porque os gestores podem realizar escolhas contábeis considerando os contextos dos países em que atuam (ZEFF, 2007).

Sarquis et al. (2014) defendem que as divergências nas práticas contábeis podem ser causadas por vários motivos, tais como a existência das escolhas contábeis, as lacunas presentes nas normas e os problemas de tradução das IFRS para a língua de cada país. Assim, os autores destacam a relevância do estudo da classificação dos sistemas contábeis para o entendimento das diferenças nas políticas contábeis das entidades de distintos países.

Nobes (2011) identificou dois grandes grupos com distintos padrões de escolhas contábeis: o grupo Anglo-Saxão, composto pelo Reino Unido, e o grupo da Europa Continental, formado por Alemanha, Espanha, França, Itália, Austrália, Países Baixos e Suécia. Posteriormente, Sarquis et al. (2014) identificaram que as escolhas contábeis dos países emergentes, tais como o Brasil, Rússia e África do Sul, também se diferem significativamente das escolhas dos países do grupo Anglo-Saxão e do grupo da Europa Continental. Assim, os autores complementaram a pesquisa de Nobes (2011) e defenderam a existência de três grupos de países com distintos sistemas de classificação contábil: Anglo-Saxão, Europa Continental e Emergentes.

Pesquisas anteriores estudaram a adoção do valor justo em países do grupo Anglo-Saxão (CAIRNS; MASSOUDI; TARCA, 2011; CHRISTENSEN; NIKOLAEV, 2013; YAO; PERCY; HU, 2015), do grupo da Europa Continental (CHRISTENSEN; NIKOLAEV, 2013; DEMARIA; DUFOUR, 2007) e do grupo dos países emergentes (BOTINHA; LEMES, 2017; TAPLIN; YUAN; BROWN, 2014). Todavia, os estudos que buscam identificar os fatores determinantes da adoção do valor justo em países com distintos sistemas de classificação contábil ainda são escassos. O estudo de Christensen e Nikolaev (2013), por exemplo, buscou verificar como alguns fatores determinantes (endividamento, desempenho econômico e porte das empresas) estavam associados com a adoção do valor justo dos ativos não financeiros (propriedades para investimentos (PPI), ativo imobilizado e ativo intangível) de empresas do Reino Unido, país do grupo Anglo-Saxão, e da Alemanha, país do grupo da Europa Continental. Todavia, os autores não avaliaram os fatores determinantes para a adoção do valor justo em países emergentes, que, conforme Sarquis et al. (2014), têm ganhado relevância na economia mundial e fomentado investimentos de outros países. O estudo de Souza e Lemes (2015), por outro lado, buscou identificar os determinantes para a adoção do valor justo na mensuração subsequente dos ativos não financeiros de companhias do Brasil, Chile e Peru. Contudo, a pesquisa desses autores tem o foco no contexto de países emergentes e não faz um confronto com os resultados de países pertencentes a outros sistemas de classificação contábil, tais como o Reino Unido e a Alemanha.

Assim, com o intuito de ampliar o entendimento sobre os fatores determinantes para a adoção do valor justo na mensuração de ativos não financeiros de companhias de distintos países, o presente trabalho almeja estender as pesquisas sobre o tema e avaliar a adoção do valor justo em países pertencentes aos 
grupos Anglo-Saxão, Europa Continental e Emergentes. Diante do exposto, a presente pesquisa tem como objetivo geral identificar os fatores que se associam a escolha do método para a mensuração de ativos não financeiros.

Para a realização da pesquisa foi selecionada uma amostra com as 50 maiores empresas, no ano de 2016, da Alemanha, pertencente ao grupo da Europa Continental, do Brasil, pertencente ao grupo dos países emergentes, e do Reino Unido, pertencente ao grupo Anglo-Saxão, totalizando 150 empresas. O período analisado foi o ano de adoção das IFRS em cada país, ou seja, 2005 para Alemanha e Reino Unido e 2010 para o Brasil. Os achados do presente estudo indicam que o custo histórico para a mensuração dos ativos não financeiros foi priorizado pelas companhias. Além disso, verificou-se que há uma postura mais conservadora da Alemanha quanto ao uso do valor justo na mensuração de ativos não financeiros. No que se refere ao Reino Unido, foi possível verificar um comportamento menos conservador, quando comparado a Alemanha. Quanto ao Brasil, identificou-se a maior adesão ao valor justo.

A importância da pesquisa se fundamenta na necessidade de identificar se as diferenças entre os sistemas de classificação contábil de cada país estão associadas à existência de diferenças nas escolhas contábeis de suas entidades, uma vez que as escolhas contábeis influenciam de forma relevante as informações a serem divulgadas aos investidores e demais usuários. Entende-se que uma avaliação da escolha das companhias entre valor justo e custo histórico é pertinente, pois, após a adoção das IFRS, os gestores passaram a ter, em maior grau, a possibilidade de escolher entre o valor justo e o custo histórico para mensurar os ativos não financeiros das entidades em que atuam. Em função da discricionariedade existente no processo de escolhas contábeis, alguns fundamentos da Abordagem Positiva da Contabilidade e da Teoria Institucional são utilizados em estudos que buscam avaliar como o país (DEMARIA; DUFOUR, 2007), o desempenho econômico (BOTINHA; LEMES, 2017; ISA, 2014), o nível de endividamento (COTTER; ZIMMER, 1995; JUNG et al., 2013; LIN; PEASNELL, 2000) e o porte das empresas (CHRISTENSEN; NIKOLAEV, 2013; DEMARIA; DUFOUR, 2007; JUNG et al., 2013) estão associados com a escolha entre o custo histórico e o valor justo para a mensuração dos ativos não circulantes. Assim, outra contribuição esperada da pesquisa é detectar os fatores que podem estar associados à adoção do valor justo nos países da amostra. Por fim, Sarquis et al. (2014) destacam que poucos estudos buscaram verificar as práticas contábeis em países emergentes. Nesse sentido, a presente pesquisa contribui ao incluir um país em desenvolvimento na amostra do estudo e se diferir das pesquisas sobre o tema (CAIRNS; MASSOUDI; TARCA, 2011; CHRISTENSEN; NIKOLAEV, 2013; DEMARIA; DUFOUR, 2007; YAO; PERCY; HU, 2015) que, comumente, abordam apenas a realidade de países desenvolvidos.

\section{Revisão da Literatura}

\subsection{Custo Histórico versus Valor Justo}

A decisão de adotar o custo histórico ou o valor justo na mensuração dos ativos não financeiros passa por um trade-off entre a confiabilidade e a relevância da informação contábil (CHRISTENSEN; NIKOLAEV, 2013). Conforme afirma Souza e Lemes (2015), ao longo de muitos anos a contabilidade mensurou os ativos e passivos por meio de valores históricos. O uso do custo histórico, porém, tem vantagens e desvantagens. Por um lado, o custo histórico pode não ser semelhante ao valor de mercado e pode não ser capaz de oferecer informações a respeito dos fluxos de caixa futuros das entidades, o que torna a informação contábil menos útil para os usuários das demonstrações financeiras. Por outro lado, o custo histórico oferece maior confiabilidade aos usuários das informações contábeis, além de ser passível de verificação (SOUZA; LEMES, 2015).

Considerando as vantagens e desvantagens do custo histórico, Christensen e Nikolaev (2013) entendem que o uso do valor justo pode apresentar maior relevância para as decisões dos usuários das demonstrações contábeis. Fargher e Zhang (2014) argumentam que o valor justo permite a obtenção de informações relacionadas a situação econômica da empresa e ainda ajuda a identificar de maneira antecipada condições adversas de mercado. Contudo, ressalta-se que quando se trata do uso do valor justo surge a preocupação com a possibilidade de manipulações. Barth (2013) destaca que alguns ativos devem ter o valor justo estimado pelos gestores, uma vez que nem todos os ativos tem prontamente valores de mercado. Assim sendo, o uso do valor justo pode propiciar menor confiança aos investidores devido a possibilidade de manipulações, erros de estimativas e a dificuldade de verificação (MCDONOUGH; SHAKESPEARE, 2015).

\subsection{Contabilidade na Alemanha, Brasil e Reino Unido}

Os fundamentos da Teoria Institucional sustentam que os gestores podem tomar as suas decisões considerando as pressões institucionais às quais estão submetidos (DIMAGGIO; POWELL, 1983). Assim, as práticas contábeis de determinadas empresas podem ser semelhantes, em função do isomorfismo, que representa a possibilidade de os gestores se sentirem impelidos a escolher métodos contábeis semelhantes 
aos utilizados por empresas que atuam sob as mesmas condições ambientais das entidades em que eles atuam (SILVA; MARTINS; LEMES, 2016).

O isomorfismo ocorre por meio de três mecanismos, sendo o isomorfismo normativo, expresso, geralmente, pelas opiniões de auditores, consultores e demais profissionais externos, o isomorfismo mimético, expresso pela possibilidade de imitação ou cópia de políticas, práticas e estratégias bem-sucedidas realizadas por organizações similares, e o isomorfismo coercitivo, que representa as pressões impostas, geralmente, pelo governo, pela sociedade ou por outras entidades das quais uma empresa dependa (DIMAGGIO; POWELL, 1983; CARPENTER; FEROZ, 2001).

As diferenças nas escolhas contábeis realizadas em distintos países podem estar associadas com o isomorfismo coercitivo, fundamentado na Teoria Institucional (SILVA; MARTINS; LEMES, 2016). As causas associadas às diferenças entre a contabilidade na Alemanha e no Reino Unido, por exemplo, podem estar ligadas às diferenças nos sistemas legais, sistemas tributários e sistemas de financiamento (NOBES, 2006). Países caracterizados pelo sistema legal code law, como a Alemanha, apresentam maior conservadorismo para a apresentação de itens no balanço patrimonial, levando a uma subvalorização dos ativos (DEMARIA; DUFOUR, 2007). Em contrapartida os países reconhecidos como commom law, por exemplo o Reino Unido, tendem a usar métodos contábeis mais conservadores relacionados ao lucro (DEMARIA; DUFOUR, 2007).

$\mathrm{Na}$ Alemanha, as companhias estão obrigadas a preparar as suas demonstrações contábeis não consolidadas em consonância com as normas emitidas pelo Handelsgesetzbuch (código comercial alemão) tanto para o cálculo do lucro tributável quanto para o lucro contábil (NOBES, 2006). Por outro lado, no Reino Unido, a aplicação das IFRS é permitida na preparação das demonstrações contábeis não consolidadas das companhias. Consequentemente, as IFRS funcionam como base para o cálculo do lucro tributável (NOBES, 2006). Outra diferença identificada entre o Reino Unido e a Alemanha está relacionada à propriedade das empresas e à forma de financiamento. No Reino Unido, a propriedade das companhias é mais dispersa, sendo que mesmo as empresas de médio porte, normalmente, estão listadas na Bolsa de Valores de Londres (CHRISTENSEN; NIKOLAEV, 2013). As empresas alemãs se caracterizam como companhias privadas que buscam capital em bancos e se comunicam por meio de canais privados de informação (LEUZ; WÜSTEMANN, 2003).

No Brasil, as IFRS passaram a ser obrigatórias para as demonstrações financeiras consolidadas no fim do ano de 2010, porém a adoção voluntária ocorreu a partir de 2007. Em países de origem code law, como o Brasil, o conservadorismo e a forma jurídica tendem a se sobressair em relação à essência econômica (COSTA; LOPES, 2015). Assim, o grupo dos países emergentes, que inclui o Brasil, apresenta características mais próximas ao grupo da Europa Continental, que também tende a ser mais conservador (SARQUIS et al., 2014).

\subsection{Escolhas Contábeis}

A regulamentação dos relatórios financeiros funciona como uma base para que as informações contábeis sejam economicamente relevantes e confiáveis. De modo geral, os regulamentos especificam as divulgações necessárias, além de requisitos e limites para a definição de critérios e divulgações voluntárias (LIBBY; RENNEKAMP; SEYBERT, 2015). No entanto, conforme afirma Silva (2016), a uniformidade dos padrões contábeis pode não retratar fidedignamente a situação econômica e financeira das empresas, impactando a qualidade da informação. Para Silva, Martins e Lemes (2016), a determinação de um único padrão contábil capaz de satisfazer às necessidades de todas as empresas é uma tarefa difícil, considerando que existem diferenças relacionadas aos mercados, à proteção ao investidor, à proteção ao credor, à regulação e ao enforcement.

Silva (2016) considera que a adoção das IFRS pode elevar o grau de comparabilidade entre empresas e países, além de estimular a representação fidedigna da realidade econômica na contabilidade. Complementando essa ideia, Santos e Calixto (2010) afirmam que com a adoção das IFRS, a contabilidade passou por uma grande transformação, passando a priorizar a essência do evento sobre a sua forma jurídica e a representação da realidade econômica. A flexibilidade existente nas normas contábeis que permitem opções para a mensuração, reconhecimento, classificação e apresentação dos eventos econômicos (SILVA, 2016) leva às escolhas contábeis. As escolhas contábeis são definidas por Watts (1992) como a opção do gestor por um método contábil em detrimento a outro.

Quando se trata dos ativos não financeiros, o ativo imobilizado, ativo intangível e PPI, as normas contábeis que determinam os critérios que estão relacionados à mensuração, reconhecimento, classificação e apresentação são respectivamente, a International Accounting Standard - IAS 16 - Property, Plant and Equipament, a International Accounting Standard -IAS 38 - Intangible Assets e a International Accounting Standard - IAS 40 - Investment Property.

A IAS 16 - Property, Plant and Equipament determina os procedimentos contábeis a serem aplicados no reconhecimento, mensuração, divulgação e baixa dos ativos imobilizados. $O$ ativo imobilizado é definido como "um item tangível mantido para uso na produção ou fornecimento de bens ou serviços, para aluguel a terceiros, ou fins administrativos e do qual espera-se que se utilize por mais de um período" (IAS 16, item 6). A IAS 16 dispõe que no reconhecimento inicial dos ativos imobilizados, estes devem ser mensurados pelo 
seu custo. Posteriormente ao reconhecimento inicial, o imobilizado pode ser mensurado pelo seu custo ou por meio de reavaliações, sendo que a reavaliação não é permitida no Brasil.

A IAS 38 - Intangible Assets estabelece o tratamento contábil a ser empregado nos ativos intangíveis. O ativo intangível é definido pela IAS 38 (item 8) como "um ativo não monetário identificável sem substância física". O ativo intangível, quando adquirido de terceiros, deve ser reconhecido inicialmente pelo custo de aquisição e, quando gerado internamente, deve ser reconhecido pelo seu custo de produção (IAS 38). Após o reconhecimento inicial, os ativos intangíveis podem ser mensurados pelo custo ou pelo modelo de reavaliação, este último não permitido no Brasil.

Com relação às PPI, a IAS 40 as define como "a propriedade (terreno ou um edifício, ou parte de um edifício, ou ambos) mantida (pelo dono ou arrendatário em um leasing financeiro) para se obter renda ou valorização de capital ou para ambas, e não para: (i) uso na produção ou suprimento de bens e serviços ou para fins administrativos; (ii) venda no curso normal do negócio" (IAS 40, item 5). A PPI deve ser reconhecida inicialmente ao custo histórico. Após o reconhecimento inicial, a PPI pode ser mensurada pelo custo histórico ou pelo método do valor justo.

$\mathrm{Na}$ adoção inicial das IFRS foi permitido que as empresas fizessem a reavaliação de seus ativos imobilizado, intangível e PPI a valor justo, por meio do uso do custo atribuído, não sendo permitido seu uso em períodos posteriores (CERQUEIRA, et al., 2012).

\subsection{Estudos Anteriores e Hipóteses do Estudo}

Demaria e Dufour (2007) buscaram identificar as escolhas contábeis de empresas francesas para a mensuração de ativos não financeiros na adoção inicial das IFRS e os possíveis determinantes para essas escolhas. Os resultados encontrados apontam que as companhias francesas optaram por manter seus ativos mensurados pelo custo histórico e que a opção pelo valor justo não está associada à alavancagem financeira, ao tamanho da empresa, à remuneração do CEO e à propriedade institucional. Demaria e Dufour (2007) avaliaram as empresas da França, que, assim como a Alemanha, pertence ao grupo Europa Continental. Entende-se que o grupo de países da Europa Continental tende a ser mais conservador, uma vez que a maior parte de seus países tem origem code law. Diante disso, espera-se que as entidades da Alemanha e do Brasil, também de origem code law, optem pelo custo histórico para a mensuração de seus ativos não financeiros.

$\mathbf{H}_{1}$ : O país em que a entidade atua apresenta associação com a escolha do método para a mensuração de cada classe dos ativos não financeiros.

Christensen e Nikolaev (2013) entendem que, normalmente, as companhias necessitam de maiores esforços e recursos para a estimação do valor justo, visto que nem todos os ativos possuem mercado ativo para a identificação deste valor. Para os autores, é mais provável a existência de um mercado ativo para PPI quando comparado ao ativo imobilizado e ao ativo intangível. Considerando o estudo de Christensen e Nikolaev (2013), presume-se que as PPI são mais comumente mensuradas pelo valor justo em relação aos demais ativos não financeiros.

$\mathbf{H}_{2}$ : A classe do ativo não financeiro apresenta associação com a escolha do método para a mensuração de ativos.

Em seu estudo, Isa (2014) argumenta que a escolha do método para mensurar os ativos não financeiros pode ter como fundamento diferentes motivações, tais como a redução ou elevação do resultado. Esse argumento fundamenta-se na Abordagem Positiva da Contabilidade, que sustenta que os gestores são racionais e que, portanto, tendem a realizar escolhas contábeis que tragam benefícios para si próprios ou para as empresas em que atuam (SCOTT, 2009). Assim, os gestores podem optar por métodos contábeis que aumentem o resultado e, consequentemente, os valores de suas remunerações (hipótese dos planos de compensação). Isso significa que, quando os gestores estão sob pressão para demonstrar um maior resultado, os mesmos tendem a adotar uma estratégia que aumenta o lucro. Botinha e Lemes (2017) destacam que a opção pelo valor justo leva a um aumento no resultado das companhias. Assim, espera-se que as companhias com maior rentabilidade tendam a ter os ativos não financeiros mensurados pelo valor justo.

$\mathbf{H}_{3}$ : A rentabilidade das entidades apresenta associação com a escolha do método para a mensuração de cada classe dos ativos não financeiros.

Alguns pesquisadores têm buscado identificar como o porte das empresas afeta a decisão sobre as políticas contábeis. Demaria e Dufour (2007) identificaram que o tamanho das entidades não estava relacionado com a adoção do valor justo. Christensen e Nikolaev (2013), por outro lado, argumentam que o custo para a mensuração do valor justo impacta menos o desempenho das grandes companhias em comparação com o desempenho das pequenas empresas e, portanto, os gestores de grandes empresas 
podem ser mais propensos a adotar o valor justo na mensuração dos ativos. De modo análogo, Jung et al. (2013) apontam que o tamanho da empresa apresenta associação com a escolha do método para a mensuração dos ativos. Diante desse contexto, espera-se que as grandes companhias tendam a mensurar os ativos não financeiros ao valor justo.

$\mathbf{H}_{4}$ : $\mathrm{O}$ porte das entidades apresenta associação com a escolha do método para a mensuração de cada classe dos ativos não financeiros.

Por fim, considerando a hipótese do grau de endividamento, presente na Abordagem Positiva da Contabilidade, conjectura-se que os gestores podem optar por políticas contábeis que aumentem o resultado e, consequentemente, evitem a violação de covenants (SCOTT, 2009). Christensen e Nikolaev (2013) estudaram os métodos para a mensuração de ativos não financeiros de entidades do Reino Unido e da Alemanha e destacaram que as companhias que buscam financiamentos externos, normalmente, necessitam fornecer garantias relacionadas ao seu desempenho organizacional e ao seu nível de endividamento. Ademais, os resultados de algumas pesquisas (COTTER; ZIMMER, 1995; JUNG et al., 2013; LIN; PEASNELL, 2000) apontam que as entidades endividadas tendem a utilizar o valor justo para evitar a violação de covenants de títulos de dívida. Dessa forma, supõe-se que as empresas com maior nível de endividamento são mais propensas a ter os ativos não financeiros mensurados pelo valor justo.

$\mathbf{H}_{5}$ : $\mathrm{O}$ nível de endividamento das entidades apresenta associação com a escolha do método para a mensuração de cada classe dos ativos não financeiros.

\section{Aspectos Metodológicos}

A amostra da pesquisa é composta por 150 empresas, compreendendo as 50 maiores de cada país da amostra. Para identificar as maiores empresas tomou-se por base o ativo total do ano de 2016. Segundo Souza e Lemes (2015), o ativo total demonstra uma estimativa do valor das companhias conforme sua perspectiva de rentabilidade futura sendo que quanto maior a empresa, maior a chance de que ela possua ativos intangíveis, ativos imobilizados e PPI. O ano de análise foi o ano da adoção das IFRS, sendo 2005 para Alemanha e Reino Unido e 2010 para o Brasil.

Foram excluídas da amostra as empresas pertencentes ao setor financeiro, visto que este setor apresenta uma legislação específica. As companhias fundadas posteriormente ao ano de adoção das IFRS na Alemanha, Brasil e Reino Unido não foram consideradas na pesquisa, uma vez que, no presente estudo foi observado o ano de adoção das IFRS e as companhias fundadas posteriormente não possuíam os dados necessários para a realização da pesquisa.

As variáveis referentes ao porte, nível de endividamento, rentabilidade e setor de atuação das entidades foram obtidas na base de dados da Thomson Reuters. Os dados referentes às escolhas contábeis foram coletados diretamente das demonstrações contábeis publicadas pelas entidades. Na coleta dos dados foi verificado se, no ano de adoção das normas contábeis, a companhia adotou custo histórico ou valor justo para a mensuração dos ativos não financeiros. Na coleta dos dados, classificou-se como "não menciona" quando a companhia dispunha do item investigado em suas demonstrações financeiras, mas não mencionava a forma de mensuração deste item em notas explicativas. Também se classificou como "não se aplica" quando, para o item verificado, não foi encontrado nenhuma menção nas demonstrações contábeis. O resumo das variáveis utilizadas na pesquisa é apresentado no Quadro 1.

\begin{tabular}{|c|c|c|}
\hline Nome & Variável & Definicão \\
\hline $\begin{array}{c}\text { Método para a mensuração do ativo } \\
\text { imobilizado }\end{array}$ & IMOB & $\begin{array}{l}\text { Custo histórico: } 0 \\
\text { Valor justo: } 1\end{array}$ \\
\hline $\begin{array}{c}\text { Método para a mensuração do ativo } \\
\text { intangível }\end{array}$ & INT & $\begin{array}{l}\text { Custo histórico: } 0 \\
\text { Valor justo: } 1\end{array}$ \\
\hline $\begin{array}{l}\text { Método para a mensuração das propriedades } \\
\text { para investimento }\end{array}$ & PPI & $\begin{array}{l}\text { Custo histórico: } 0 \\
\text { Valor justo: } 1\end{array}$ \\
\hline Tamanho do ativo & TAM & Logaritmo natural do valor do ativo no final do ano \\
\hline Nível de endividamento & END & $\begin{array}{l}\text { Total do passivo } \\
\text { Passivo e patrimônio líquido }\end{array}$ \\
\hline Retorno sobre o Patrimônio Líquido & ROE & $\begin{array}{l}\text { Lucro líquido } \\
\text { Patrimônio líquido }\end{array}$ \\
\hline País & PAIS & $\begin{array}{l}\text { Alemanha: } 1 \\
\text { Brasil: } 2 \\
\text { Reino Unido: } 3\end{array}$ \\
\hline
\end{tabular}

\footnotetext{
Fonte: Elaborado pelas autoras.
}

Utilizou-se o Teste Qui-quadrado para tratar os dados do presente estudo, o qual tem por objetivo identificar se duas ou mais amostras são estatisticamente distintas em alguma categoria (LEVINE et al., 2000). De acordo com Fávero et al. (2009), a estatística do Teste Qui-quadrado é dada pela diferença entre as 
frequências observadas e esperadas divididas pela frequência esperada em cada categoria. A estatística do Teste Qui-quadrado é igual:

$$
\chi^{2}=\sum \frac{\left(f_{0}-f_{e}\right)^{2}}{f_{e}}
$$

Onde:

$f_{0}=$ frequência observada em cada categoria.

$f_{e}=$ frequência esperada em cada categoria.

$10 \%$.

O nível de significância empregado para rejeição ou aceitação das hipóteses foi de $\alpha=1 \%, 5 \%$ e

Destaca-se que as variáveis referentes ao tamanho do ativo (TAM), nível de endividamento (END) e Retorno sobre o Patrimônio Líquido (ROE) das entidades foram divididas em tercis para a realização dos testes qui-quadrado.

\section{Apresentação e Análise dos Resultados}

$\mathrm{Na}$ Tabela 1 são apresentadas as escolhas para a mensuração dos ativos não financeiros das companhias dos três países segregadas por setor para melhor categorização e entendimento das escolhas. É possível identificar que $86 \%$ das companhias da amostra optam por mensurar seus ativos imobilizados pelo método do custo histórico, enquanto $14 \%$ utilizaram o valor justo, o resultado corrobora Demaria e Dufour (2007). Segundo os autores, o uso contínuo do valor justo tende a ser incomum para o ativo imobilizado.

Tabela 1 - Escolhas contábeis na adoção das IFRS - Amostra Total

\begin{tabular}{|c|c|c|c|c|c|c|c|c|c|c|c|c|c|c|c|}
\hline \multirow{3}{*}{ Setor } & \multicolumn{5}{|c|}{ Imobilizado } & \multicolumn{5}{|c|}{ Intangível } & \multicolumn{5}{|c|}{ PPI } \\
\hline & \multicolumn{2}{|c|}{$\mathrm{CH}$} & \multicolumn{2}{|r|}{ VJ } & \multirow{2}{*}{$\begin{array}{c}\text { Total } \\
\mathrm{N}\end{array}$} & \multicolumn{2}{|c|}{$\mathrm{CH}$} & \multicolumn{2}{|r|}{ VJ } & \multirow{2}{*}{$\begin{array}{c}\text { Total } \\
\mathrm{N}\end{array}$} & \multicolumn{2}{|r|}{$\mathrm{CH}$} & \multicolumn{2}{|r|}{ VJ } & \multirow{2}{*}{$\begin{array}{c}\text { Total } \\
\mathrm{N}\end{array}$} \\
\hline & $\mathrm{N}$ & $\%$ & $\mathrm{~N}$ & $\%$ & & $\mathrm{~N}$ & $\%$ & $\mathrm{~N}$ & $\%$ & & $\mathrm{~N}$ & $\%$ & $\mathrm{~N}$ & $\%$ & \\
\hline Materiais Básicos & 17 & 85,00 & 3 & 15,00 & 20 & 14 & 82,35 & 3 & 17,65 & 17 & 5 & 100,00 & 0 & 0,00 & 5 \\
\hline Consumo Cíclico & 29 & 96,67 & 1 & 3,33 & 30 & 25 & 96,15 & 1 & 3,85 & 26 & 8 & 88,89 & 1 & 11,11 & 9 \\
\hline Consumo Não Cíclico & 12 & 85,71 & 2 & 14,29 & 14 & 12 & 85,71 & 2 & 14,29 & 14 & 1 & 100,00 & 0 & 0,00 & 1 \\
\hline Energia & 8 & 100,00 & 0 & 0,00 & 8 & 7 & 100,00 & 0 & 0,00 & 7 & 0 & 0,00 & 0 & 0,00 & 0 \\
\hline Saúde & 8 & 100,00 & 0 & 0,00 & 8 & 7 & 87,50 & 1 & 12,50 & 8 & 0 & 0,00 & 0 & 0,00 & 0 \\
\hline Indústria & 21 & 84,00 & 4 & 16,00 & 25 & 20 & 90,91 & 2 & 9,09 & 22 & 6 & 100,00 & 0 & 0,00 & 6 \\
\hline Tecnologia & 3 & 100,00 & 0 & 0,00 & 3 & 3 & 100,00 & 0 & 0,00 & 3 & 0 & 0,00 & 0 & 0,00 & 0 \\
\hline Telecomunicações & 7 & 100,00 & 0 & 0,00 & 7 & 7 & 100,00 & 0 & 0,00 & 7 & 1 & 100,00 & 0 & 0,00 & 1 \\
\hline Utilidades & 15 & 60,00 & 10 & 40,00 & 25 & 17 & 68,00 & 8 & 32,00 & 25 & 4 & 100,00 & 0 & 0,00 & 4 \\
\hline Total & 120 & 86 & 20 & 14 & 140 & 112 & 87 & 17 & 13 & 129 & 25 & 96 & 1 & 4 & 26 \\
\hline
\end{tabular}

Fonte: Elaborado pelas autoras

Com relação ao ativo intangível verifica-se (Tabela 1) que a preferência das companhias também é pelo custo histórico (87\%), logo, a adoção do valor justo na mensuração do intangível é de $13 \%$. A demonstrada preferência das companhias pelo custo histórico pode estar relacionada a complexidade na mensuração dos intangíveis. No que se refere às PPI, 96\% das empresas adotam o custo histórico como forma de mensuração, enquanto apenas $4 \%$ mensuram as PPI por meio do valor justo (Tabela 1). É pertinente destacar que apenas uma empresa utilizou o valor justo para mensurar as PPI e esse resultado está em concordância com o verificado por Christensen e Nikolaev (2009).

$\mathrm{Na}$ Tabela 2 são expostas as escolhas dos métodos para a mensuração dos ativos não financeiros na Alemanha.

Tabela 2 - Escolhas contábeis na adoção inicial das IFRS - Alemanha

\begin{tabular}{|c|c|c|c|c|c|c|c|c|c|c|c|c|c|c|c|}
\hline \multirow{3}{*}{ Setor } & \multicolumn{5}{|c|}{ Imobilizado } & \multicolumn{5}{|c|}{ Intangível } & \multicolumn{5}{|c|}{ PPI } \\
\hline & \multicolumn{2}{|c|}{$\mathrm{CH}$} & \multicolumn{2}{|c|}{ VJ } & \multirow{2}{*}{$\begin{array}{c}\text { Total } \\
\mathrm{N}\end{array}$} & \multicolumn{2}{|c|}{$\mathrm{CH}$} & \multicolumn{2}{|c|}{ VJ } & \multirow{2}{*}{$\begin{array}{c}\text { Total } \\
\mathrm{N}\end{array}$} & \multicolumn{2}{|c|}{$\mathrm{CH}$} & \multicolumn{2}{|c|}{ VJ } & \multirow{2}{*}{$\begin{array}{c}\text { Total } \\
\mathrm{N}\end{array}$} \\
\hline & $\mathrm{N}$ & $\%$ & $\mathrm{~N}$ & $\%$ & & $\mathrm{~N}$ & $\%$ & $\mathrm{~N}$ & $\%$ & & $\mathrm{~N}$ & $\%$ & $\mathrm{~N}$ & $\%$ & \\
\hline Materiais Básicos & 8 & 100,00 & 0 & 0,00 & 8 & 8 & 100,00 & 0 & 0,00 & 8 & 4 & 100,00 & 0 & 0,00 & 4 \\
\hline Consumo Cíclico & 15 & 100,00 & 0 & 0,00 & 15 & 15 & 100,00 & 0 & 0,00 & 15 & 6 & 100,00 & 0 & 0,00 & 6 \\
\hline Consumo Não Cíclico & 4 & 100,00 & 0 & 0,00 & 4 & 4 & 100,00 & 0 & 0,00 & 4 & 1 & 100,00 & 0 & 0,00 & 1 \\
\hline Energia & 0 & 0,00 & 0 & 0,00 & 0 & 0 & 0,00 & 0 & 0,00 & 0 & 0 & 0,00 & 0 & 0,00 & 0 \\
\hline Saúde & 4 & 100,00 & 0 & 0,00 & 4 & 4 & 100,00 & 0 & 0,00 & 4 & 0 & 0,00 & 0 & 0,00 & 0 \\
\hline Indústria & 11 & 100,00 & 0 & 0,00 & 11 & 11 & 100,00 & 0 & 0,00 & 11 & 5 & 100,00 & 0 & 0,00 & 5 \\
\hline Tecnologia & 2 & 100,00 & 0 & 0,00 & 2 & 2 & 100,00 & 0 & 0,00 & 2 & 0 & 0,00 & 0 & 0,00 & 0 \\
\hline Telecomunicações & 1 & 100,00 & 0 & 0,00 & $\overline{1}$ & 1 & 100,00 & 0 & 0,00 & 1 & 1 & 100,00 & 0 & 0,00 & 1 \\
\hline Utilidades & 3 & 100,00 & 0 & 0,00 & 3 & 3 & 100,00 & 0 & 0,00 & 3 & 2 & 100,00 & 0 & 0,00 & 2 \\
\hline Total & 48 & 100 & 0 & 0 & 48 & 48 & 100 & 0 & 0 & 48 & 19 & 100 & 0 & 0 & 19 \\
\hline
\end{tabular}

Fonte: Elaborado pelas autoras

Com relação às empresas alemãs, destaca-se (Tabela 2) que nenhuma empresa do estudo adotou o valor justo na mensuração do ativo imobilizado, do ativo intangível e das PPI. Uma possível explicação para este resultado pode estar ligada ao fato de que a norma contábil anterior do país não permitia o uso do valor justo. Além disso, deve-se levar em consideração, os custos relacionados à alteração das escolhas contábeis. 
Mudanças relacionadas às práticas implicam renegociações de contratos de dívida e remuneração e precisam ser explicadas aos auditores e informadas a acionistas, o que poderia tornar a mudança da prática contábil pouco atraente (CHRISTENSEN; NIKOLAEV, 2013). A Tabela 3 exibe as escolhas dos métodos para a mensuração dos ativos não financeiros das companhias brasileiras. No que se refere às companhias brasileiras, percebe-se que o valor justo foi mais utilizado na mensuração do ativo intangível $(32,61 \%)$, seguido do ativo imobilizado $(31,25 \%)$. Ressalta-se que esse resultado está relacionado ao uso do custo atribuído pelas empresas, uma vez que a mensuração do ativo imobilizado e intangível por meio do valor justo não é permitida no Brasil. Quanto às PPI, destaca-se que apenas uma empresa brasileira possuía PPI, sendo que a opção dela foi pelo custo histórico.

Tabela 3 - Escolhas contábeis na adoção inicial das IFRS - Brasil

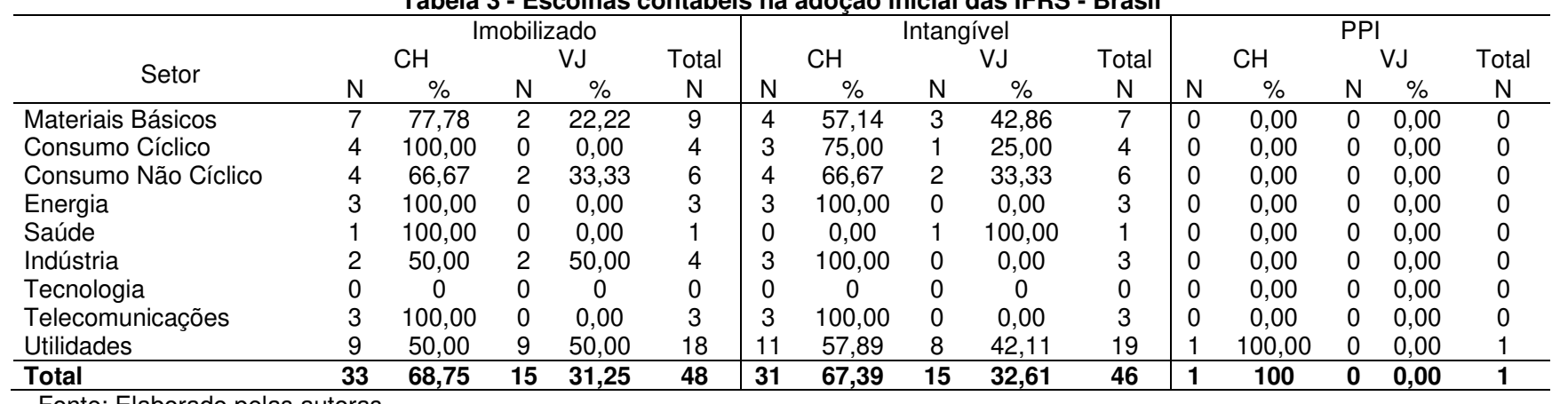

Fonte: Elaborado pelas autoras

$\mathrm{Na}$ Tabela 4 são evidenciados os resultados referentes às escolhas dos métodos para a mensuração dos ativos não financeiros de entidades do Reino Unido.

Tabela 4 - Escolhas contábeis na adoção inicial das IFRS - Reino Unido

\begin{tabular}{|c|c|c|c|c|c|c|c|c|c|c|c|c|c|c|c|}
\hline \multirow{3}{*}{ Setor } & \multicolumn{5}{|c|}{ Imobilizado } & \multicolumn{5}{|c|}{ Intangível } & \multicolumn{5}{|c|}{ PPI } \\
\hline & \multicolumn{2}{|c|}{$\mathrm{CH}$} & \multicolumn{2}{|c|}{ VJ } & \multirow{2}{*}{$\begin{array}{c}\text { Total } \\
\mathrm{N}\end{array}$} & \multicolumn{2}{|c|}{$\mathrm{CH}$} & \multicolumn{2}{|c|}{ VJ } & \multirow{2}{*}{$\begin{array}{c}\text { Total } \\
\mathrm{N}\end{array}$} & \multicolumn{2}{|r|}{$\mathrm{CH}$} & \multicolumn{2}{|c|}{ VJ } & \multirow{2}{*}{$\begin{array}{c}\text { Total } \\
\mathrm{N}\end{array}$} \\
\hline & $\mathrm{N}$ & $\%$ & $\mathrm{~N}$ & $\%$ & & $\mathrm{~N}$ & $\%$ & $\mathrm{~N}$ & $\%$ & & $\mathrm{~N}$ & $\%$ & $\mathrm{~N}$ & $\%$ & \\
\hline Materiais Básicos & 2 & 66,67 & 1 & 33,33 & 3,00 & 2 & 100,00 & 0 & 0,00 & 2 & 1 & 100,00 & 0 & 0,00 & 1 \\
\hline Consumo Cíclico & 10 & 90,91 & 1 & 9,09 & 11,00 & 7 & 100,00 & 0 & 0,00 & 7 & 2 & 66,67 & 1 & 33,33 & 3 \\
\hline Consumo Não Cíclico & 4 & 100,00 & 0 & 0,00 & 4,00 & 4 & 100,00 & 0 & 0,00 & 4 & 0 & 0 & 0 & 0 & 0 \\
\hline Energia & 5 & 100,00 & 0 & 0,00 & 5,00 & 4 & 100,00 & 0 & 0,00 & 4 & 0 & 0 & 0 & 0 & 0 \\
\hline Saúde & 3 & 100,00 & 0 & 0,00 & 3,00 & 3 & 100,00 & 0 & 0,00 & 3 & 0 & 0 & 0 & 0 & 0 \\
\hline Indústria & 8 & 80,00 & 2 & 20,00 & 10,00 & 6 & 75,00 & 2 & 25,00 & 8 & 1 & 100,00 & 0 & 0,00 & 1 \\
\hline Tecnologia & 1 & 100,00 & 0 & 0,00 & 1,00 & 1 & 100,00 & 0 & 0,00 & 1 & 0 & 0 & 0 & 0 & 0 \\
\hline Telecomunicações & 3 & 100,00 & 0 & 0,00 & 3,00 & 3 & 100,00 & 0 & 0,00 & 3 & 0 & 0 & 0 & 0 & 0 \\
\hline Utilidades & 3 & 75,00 & 1 & 25,00 & 4,00 & 3 & 100,00 & 0 & 0,00 & 3 & 1 & 100,00 & 0 & 0,00 & 1 \\
\hline Total & 39 & 88,64 & 5 & 11,36 & 44 & 33 & 94,29 & 2 & 5,71 & 35 & 5 & 83,33 & 1 & 16,67 & 6 \\
\hline
\end{tabular}

Fonte: Elaborado pelas autoras

Quanto às empresas do Reino Unido, ressalta-se (Tabela 4) que uma companhia do país adotou o valor justo para a mensuração das PPI. No que se refere ao ativo imobilizado e ao ativo intangível, percebese que o percentual de uso do custo histórico é alto, sendo $88,64 \%$ e $94,29 \%$, respectivamente.

A Tabela 5 expõe os resultados para as escolhas dos métodos de mensuração agrupados de acordo com a classe do ativo.

Tabela 5 - Valor Justo de acordo com a classe do ativo

\begin{tabular}{|c|c|c|c|c|c|c|c|c|c|}
\hline \multirow{2}{*}{\multicolumn{2}{|c|}{$\begin{array}{l}\text { Total de empresas que usam o valor justo por } \\
\text { classe do ativo }\end{array}$}} & \multicolumn{2}{|c|}{ Alemanha } & \multicolumn{2}{|c|}{ Brasil } & \multicolumn{2}{|c|}{ Reino Unido } & \multicolumn{2}{|c|}{ Amostra Total } \\
\hline & & $\mathrm{N}$ & $\%$ & $\mathrm{~N}$ & $\%$ & $\mathrm{~N}$ & $\%$ & $\mathrm{~N}$ & $\%$ \\
\hline & Imobilizado & 0 & 0 & 15 & 31,25 & 5 & 11,36 & 20 & 14,29 \\
\hline & Intangível & 0 & 0 & 15 & 32,61 & 2 & 5,71 & 17 & 13,18 \\
\hline & PPI & 0 & 0 & 0 & 0 & 1 & 16,67 & 1 & 3,85 \\
\hline
\end{tabular}

Fonte: Elaborado pelas autoras

Identificou-se (Tabela 5) que o valor justo foi utilizado para a mensuração do ativo imobilizado de $31,25 \%$ das entidades do Brasil e de $11,36 \%$ das empresas britânicas. Conforme mencionado anteriormente, as companhias alemãs do estudo não adotaram o valor justo para os ativos investigados. Destaca-se também que apenas uma companhia da amostra adotou o valor justo para mensurar as PPI.

Para testar a Hipótese $1\left(\mathrm{H}_{1}\right)$, em que se supôs que o país em que a entidade atua está associado com a escolha do método de mensuração, foram realizados testes Qui-quadrado para cada grupo de ativos não financeiros. A Tabela 6 reporta os métodos utilizados para a mensuração do ativo imobilizado em cada um dos três países da amostra.

O Teste Qui-quadrado ( $p$-valor $=0,000$ ) indica (Tabela 6) que a escolha do método de mensuração do imobilizado está associada com os países das entidades, sendo que o Brasil é o país que tem o maior percentual $(31,25 \%)$ de empresas que adotaram o valor justo. No entanto, é relevante salientar, como já 
mencionado, que esse percentual se deve a possibilidade do uso do custo atribuído na adoção inicial da norma, uma vez que o uso do valor justo para a mensuração do imobilizado não é permitido no Brasil.

\begin{tabular}{ccccccc}
\multicolumn{6}{c}{ Tabela 6 - Associação entre o método de mensuração do imobilizado e o país } \\
\hline \multicolumn{2}{c}{ Ativo Imobilizado } & & Alemanha & Brasil & Reino Unido & Total \\
\hline \multirow{2}{*}{ Frequência } & Custo Histórico & 48 & 33 & 39 & 120 \\
& Valor Justo & 0 & 15 & 5 & 20 \\
& Total & 48 & 48 & 44 & 140 \\
\hline \multirow{2}{*}{ Percentual } & Custo Histórico & $100 \%$ & $68,75 \%$ & $88,64 \%$ & $85,71 \%$ \\
& Valor Justo & $0,00 \%$ & $31,25 \%$ & $11,36 \%$ & $14,29 \%$ \\
& Total & $100 \%$ & $100 \%$ & $100 \%$ & $100 \%$ \\
\hline
\end{tabular}

Fonte: Elaborado pelas autoras

Destaca-se também que nenhuma empresa alemã optou por mensurar seu imobilizado pelo valor justo na adoção inicial das IFRS. Esse resultado aproxima-se do encontrado por Christensen e Nikolaev (2013). Os referidos autores, a partir de uma amostra de 605 empresas alemãs que possuíam ativos imobilizados, identificaram que apenas sete adotaram o valor justo na mensuração inicial do imobilizado (CHRISTENSEN; NIKOLAEV, 2013). Uma possível explicação para este resultado é o fato de que o GAAP anterior da Alemanha não permitia a adoção do valor justo.

Acerca do ativo intangível, é possível perceber que as empresas brasileiras tiveram maior percentual $(32,61 \%)$ de uso do valor justo na adoção inicial das IFRS, devido ao uso do custo atribuído (Tabela 7).

Tabela 7 - Associação entre o método de mensuração do intangível e o país

\begin{tabular}{|c|c|c|c|c|c|}
\hline \multicolumn{2}{|c|}{ Ativo Intangível } & Alemanha & Brasil & Reino Unido & Total \\
\hline \multirow{3}{*}{ Frequência } & Custo Histórico & 48 & 31 & 33 & 112 \\
\hline & Valor Justo & 0 & 15 & 2 & 17 \\
\hline & Total & 48 & 46 & 35 & 129 \\
\hline \multirow{3}{*}{ Percentual } & Custo Histórico & $100 \%$ & $67,39 \%$ & $94,29 \%$ & $86,82 \%$ \\
\hline & Valor Justo & $0,00 \%$ & $32,61 \%$ & $5,71 \%$ & $13,18 \%$ \\
\hline & Total & $100 \%$ & $100 \%$ & $100 \%$ & $100 \%$ \\
\hline
\end{tabular}

Fonte: Elaborado pelas autoras

Por meio do Teste Qui-quadrado ( $p$-valor $=0,000$ ) verificou-se (Tabela 7$)$ que a escolha do método de mensuração do intangível está associada com os países, sendo que as empresas brasileiras foram mais propensas a escolher o valor justo na adoção inicial das IFRS. Como pode ser observado na Tabela 7, apenas duas empresas do Reino Unido optaram pela adesão ao valor justo. Com relação às empresas alemãs, destaca-se que nenhuma companhia mensurou os ativos intangíveis por meio do valor justo, resultado semelhante ao identificado por Christensen e Nikolaev (2013).

Na Tabela 8 são identificados os métodos utilizados para a mensuração das PPI nos três países da amostra.

Tabela 8 - Associacão entre o método de mensuracão das PPI e o país

\begin{tabular}{|c|c|c|c|c|c|}
\hline & & Alemanha & Brasil & Reino Unido & Total \\
\hline \multirow{3}{*}{ Frequência } & Custo Histórico & 19 & 1 & 5 & 25 \\
\hline & Valor Justo & 0 & 0 & 1 & 1 \\
\hline & Total & 19 & 1 & 6 & 26 \\
\hline \multirow{3}{*}{ Percentual } & Custo Histórico & $100 \%$ & $100 \%$ & $83,33 \%$ & $96,15 \%$ \\
\hline & Valor Justo & $0,00 \%$ & $0,00 \%$ & $16,67 \%$ & $3,85 \%$ \\
\hline & Total & $100 \%$ & $100 \%$ & $100 \%$ & $100 \%$ \\
\hline
\end{tabular}

Fonte: Elaborado pelas autoras

O Teste Qui-quadrado ( $p$-valor $=0,177$ ) aponta (Tabela 8 ) que a escolha do método de mensuração das PPI não está associada com os países das entidades. Especificamente, destaca-se que apenas uma companhia do Reino Unido adotou o valor justo na mensuração de PPI. A Alemanha possui o maior número de empresas com PPI. Apesar disso, todas as companhias alemãs optaram por usar o custo histórico na mensuração das PPI. Quanto ao Brasil, apenas uma empresa da amostra apresentou PPI, sendo que essa entidade também optou pelo uso do custo histórico. Segundo Botinha e Lemes (2017) a preferência das companhias por mensurar suas PPI por meio do custo histórico pode ser explicada por uma relutância na mudança da prática contábil, uma vez que os gestores tendem a manter a prática anterior, evitando mudanças significativas. A propensão pelo uso do custo histórico também pode estar ligada à dificuldade de implementação do valor justo e à incerteza a respeito do valor justo (BOTINHA; LEMES, 2017).

O resultado do Teste Qui-quadrado ( $p$-valor $=0,291$ ) aponta (Tabela 9) que a rentabilidade das entidades não está associada com a escolha do método de mensuração do imobilizado na adoção inicial das IFRS.

Ressalta-se (Tabela 9) que, entre as empresas mais rentáveis, $84,78 \%$ optaram por usar o custo histórico na mensuração dos ativos imobilizados. As empresas com menor rentabilidade apresentaram maior adesão ao uso do valor justo na adoção inicial das IFRS, sendo que aproximadamente $19,57 \%$ optaram pela mensuração de seu imobilizado pelo valor justo. Das companhias que apresentam rentabilidade média, 91,67\% adotaram o custo histórico para mensurar o ativo imobilizado (Tabela 9). 
Tabela 9 - Associação entre a rentabilidade e o método de mensuração do ativo imobilizado

\begin{tabular}{cccccc}
\hline \multicolumn{2}{c}{ Ativo Imobilizado } & Menor Rentabilidade & Média Rentabilidade & Maior Rentabilidade & Total \\
\hline \multirow{3}{*}{ Frequência } & Custo Histórico & 37 & 44 & 39 & 120 \\
& Valor Justo & 9 & 4 & 7 & 20 \\
& Total & 46 & 48 & 46 & 140 \\
\hline \multirow{3}{*}{ Percentual } & Custo Histórico & $80,43 \%$ & $91,67 \%$ & $84,78 \%$ & $85,71 \%$ \\
& Valor Justo & $19,57 \%$ & $8,33 \%$ & $15,22 \%$ & $14,29 \%$ \\
& Total & $100 \%$ & $100 \%$ & $100 \%$ & $100 \%$ \\
\hline Fonte: Elaborado
\end{tabular}

Fonte: Elaborado pelas autoras

A Tabela 10 indica os métodos escolhidos para a mensuração do ativo intangível das entidades com distintos níveis de rentabilidade.

Tabela 10 - Associação entre a rentabilidade e o método escolhido para a mensuração do ativo intangível

\begin{tabular}{|c|c|c|c|c|c|}
\hline \multicolumn{2}{|c|}{ Ativo Intangível } & Menor Rentabilidade & Média Rentabilidade & Maior Rentabilidade & Total \\
\hline \multirow{3}{*}{ Frequência } & Custo Histórico & 36 & 38 & 38 & 112 \\
\hline & Valor Justo & 6 & 5 & 6 & 17 \\
\hline & Total & 42 & 43 & 44 & 129 \\
\hline \multirow{3}{*}{ Percentual } & Custo Histórico & $85,71 \%$ & $88,37 \%$ & $86,36 \%$ & $86,82 \%$ \\
\hline & Valor Justo & $14,29 \%$ & $11,63 \%$ & $13,64 \%$ & $13,18 \%$ \\
\hline & Total & $100 \%$ & $100 \%$ & $100 \%$ & $100 \%$ \\
\hline
\end{tabular}

Fonte: Elaborado pelas autoras

No que se refere à mensuração do ativo intangível, as companhias com menor rentabilidade apresentam maior percentual $(14,29 \%)$ de uso do valor justo quando comparadas às empresas de média e alta rentabilidade (Tabela 10). O Teste Qui-quadrado ( $p$-valor $=0,931)$ não indica a associação entre o método de mensuração do ativo intangível e a rentabilidade. Ressalta-se que as empresas com média rentabilidade têm o maior percentual de adoção $(88,37 \%)$ do custo histórico.

Quanto à mensuração das PPI, identificou-se (Tabela 11) que $100 \%$ das companhias de média e maior rentabilidade optaram por adotar o custo histórico, conforme exposto na Tabela 11. A única companhia a adotar o valor justo para as PPI apresenta menor rentabilidade. O Teste Qui-quadrado ( $p$-valor $=0,374)$ não indicou associação entre a rentabilidade e a escolha do método para a mensuração de PPI.

Os resultados aqui encontrados corroboram a afirmação de Jung et al. (2013). Segundo os autores, os gestores de companhias com menor desempenho operacional seriam mais resistentes em adotar o valor justo para os ativos não financeiros. As avaliações pelo valor justo não influenciam o lucro líquido, contudo afetam as medidas de desempenho operacional, o que justificaria a resistência dos gestores na adoção do valor justo em empresas menos rentáveis.

\begin{tabular}{|c|c|c|c|c|c|}
\hline & & Menor Rentabilidade & Média Rentabilidade & Maior Rentabilidade & Total \\
\hline \multirow{3}{*}{ Frequência } & Custo Histórico & 8 & 9 & 8 & 25 \\
\hline & Valor Justo & 1 & 0 & 0 & 1 \\
\hline & Total & 9 & 9 & 8 & 26 \\
\hline \multirow{3}{*}{ Percentual } & Custo Histórico & $88,89 \%$ & $100 \%$ & $100 \%$ & $96,15 \%$ \\
\hline & Valor Justo & $11,11 \%$ & $0,00 \%$ & $0,00 \%$ & $3,85 \%$ \\
\hline & Total & $100 \%$ & $100 \%$ & $100 \%$ & $100 \%$ \\
\hline
\end{tabular}

Fonte: Elaborado pelas autoras.

Com relação ao ativo imobilizado, o Teste Qui-quadrado $(p$-valor $=0,059)$ revela associação entre o tamanho da empresa e a escolha do método para a mensuração do imobilizado. Destaca-se que o percentual de grandes empresas $(93,62 \%)$ que adotaram o custo histórico é maior do que os percentuais de pequenas $(86,96 \%)$ e médias empresas $(76,60 \%)$ que usaram o custo histórico para mensurar o imobilizado. Com relação ao uso do valor justo (Tabela 12), as médias empresas evidenciam o maior percentual de adoção do valor justo $(23,40 \%)$ quando comparadas com as pequenas $(13,04 \%)$ e grandes empresas $(6,38 \%)$.

Tabela 12 - Associação entre o tamanho da entidade e o método de mensuração do imobilizado

\begin{tabular}{|c|c|c|c|c|c|}
\hline \multicolumn{2}{|c|}{ Ativo Imobilizado } & Pequena & Média & Grande & Total \\
\hline \multirow{3}{*}{ Frequência } & Custo Histórico & 40 & 36 & 44 & 120 \\
\hline & Valor Justo & 6 & 11 & 3 & 20 \\
\hline & Total & 46 & 47 & 47 & 140 \\
\hline \multirow{3}{*}{ Percentual } & Custo Histórico & $86,96 \%$ & $76,60 \%$ & $93,62 \%$ & $85,71 \%$ \\
\hline & Valor Justo & $13,04 \%$ & $23,40 \%$ & $6,38 \%$ & $14,29 \%$ \\
\hline & Total & $100 \%$ & $100 \%$ & $100 \%$ & $100 \%$ \\
\hline
\end{tabular}

Fonte: Elaborado pelas autoras

A Tabela 13 indica os métodos utilizados para a mensuração do ativo intangível de entidades com distintos portes. 
Tabela 13 - Associação entre o tamanho da entidade e o método de mensuração do ativo intangível

\begin{tabular}{|c|c|c|c|c|c|}
\hline \multicolumn{2}{|c|}{ Ativo Intangível } & Pequena & Média & Grande & Total \\
\hline \multirow{3}{*}{ Frequência } & Custo Histórico & 35 & 38 & 39 & 112 \\
\hline & Valor Justo & 5 & 7 & 5 & 17 \\
\hline & Total & 40 & 45 & 44 & 129 \\
\hline \multirow{3}{*}{ Percentual } & Custo Histórico & $88 \%$ & $84,44 \%$ & $88,64 \%$ & $86,82 \%$ \\
\hline & Valor Justo & $13 \%$ & $15,56 \%$ & $11,36 \%$ & $13,18 \%$ \\
\hline & Total & $100 \%$ & $100 \%$ & $100 \%$ & $100 \%$ \\
\hline
\end{tabular}

Fonte: Elaborado pelas autoras

Por meio do Teste Qui-quadrado ( $p$-valor $=0,833$ ) não foi identificada associação entre o tamanho da empresa e a escolha do método para a mensuração do ativo intangível. Destaca-se que as empresas que tiveram maior percentual de adoção do valor justo (15,56\%) pertencem ao grupo das médias empresas. Com relação ao percentual de uso do custo histórico, as pequenas e grandes empresas dispuseram de percentuais próximos, de $88 \%$ e $88,64 \%$, respectivamente.

No que se refere às PPI, destaca-se que apenas uma companhia, pertencente ao grupo das pequenas empresas, adotou o valor justo, conforme exposto na Tabela 14.

Tabela 14 - Associação entre o tamanho da entidade e o método de mensuração das PPI

\begin{tabular}{|c|c|c|c|c|c|}
\hline & & Pequena & Média & Grande & Total \\
\hline \multirow{3}{*}{ Frequência } & Custo Histórico & 7 & 7 & 11 & 25 \\
\hline & Valor Justo & 1 & 0 & 0 & 1 \\
\hline & Total & 8 & 7 & 11 & 26 \\
\hline \multirow{3}{*}{ Percentual } & Custo Histórico & $87,50 \%$ & $100 \%$ & $100 \%$ & $96,15 \%$ \\
\hline & Valor Justo & $12,50 \%$ & $0,00 \%$ & $0,00 \%$ & $3,85 \%$ \\
\hline & Total & $100 \%$ & $100 \%$ & $100 \%$ & $100 \%$ \\
\hline
\end{tabular}

Fonte: Elaborado pelas autoras

O Teste Qui-Quadrado ( $p$-valor $=0,310$ ) não indica a associação entre o método escolhido para a mensuração das PPI e o tamanho da empresa. Destaca-se também que todas as médias e grandes companhias optaram pelo uso do custo histórico.

Com relação a associação entre o porte das companhias e a mensuração do valor justo, os resultados apontaram a associação apenas entre a mensuração do ativo imobilizado e o porte das empresas. Adicionalmente, contrariando o que se esperava, as empresas que mais adotaram o valor justo pertencem ao grupo de pequeno e médio portes. Esperava-se, de modo geral, que as companhias de grande porte teriam maior percentual de adesão ao valor justo, levando em consideração os custos relacionados a mudança para a mensuração pelo valor justo. Contudo, conforme afirmam Jung et al. (2013), os acionistas de companhias de grande porte têm possibilidade de obter informações em fontes distintas. Por outro lado, para obter as informações financeiras, os investidores de companhias de pequeno e médio portes tem maior dependência dos relatórios financeiros. Nesse sentido, o maior percentual de adesão ao valor justo nessas empresas estaria ligado a uma redução na assimetria de informação entre os gerentes e acionistas (JUNG et al., (2013).

Reporta-se na Tabela 15 os métodos para a mensuração do ativo imobilizado de empresas com distintos níveis de endividamento.

Tabela 15 - Associação entre o endividamento e o método de mensuração do imobilizado

\begin{tabular}{|c|c|c|c|c|c|}
\hline \multicolumn{2}{|c|}{ Ativo Imobilizado } & Baixo Endividamento & Médio Endividamento & Alto Endividamento & Total \\
\hline \multirow{3}{*}{ Frequência } & Custo Histórico & 41 & 34 & 45 & 120 \\
\hline & Valor Justo & 6 & 11 & 3 & 20 \\
\hline & Total & 47 & 45 & 48 & 140 \\
\hline \multirow{3}{*}{ Percentual } & Custo Histórico & $87,23 \%$ & $75,56 \%$ & $93,75 \%$ & $85,71 \%$ \\
\hline & Valor Justo & $12,77 \%$ & $24,44 \%$ & $6,25 \%$ & $14,29 \%$ \\
\hline & Total & $100 \%$ & $100 \%$ & $100 \%$ & $100 \%$ \\
\hline
\end{tabular}

Fonte: Elaborado pelas autoras

O Teste Qui-quadrado ( $p$-valor $=0,041$ ) aponta (Tabela 15$)$ a associação entre o endividamento das empresas e a escolha do valor justo para a mensuração do ativo imobilizado. Destaca-se que as empresas com um nível médio de endividamento têm maior percentual de uso do valor justo $(24,44 \%)$. Com relação às empresas mais endividadas, percebe-se que as mesmas possuem o menor percentual de adoção do valor justo $(6,25 \%)$, indicando uma preferência pelo custo histórico na mensuração dos itens do ativo imobilizado. Das empresas com baixo endividamento, $87,23 \%$ optaram pelo uso do custo histórico, enquanto $12,77 \%$ utilizaram o valor justo para a mensuração do ativo imobilizado.

A Tabela 16 expõe os métodos para a mensuração do ativo intangível de empresas com distintos níveis de endividamento. Por meio do Teste Qui-quadrado ( $p$-valor $=0,623$ ) não foi identificada associação entre o endividamento e a escolha do método para a mensuração do ativo intangível. No entanto, é possível perceber que as companhias que possuem um baixo nível de endividamento têm o maior percentual de uso do valor justo $(17,50 \%)$. Ressalta-se também que as companhias com médio e alto nível de endividamento, possuem os percentuais de adoção do valor justo e do custo histórico muito próximos. Enquanto 11,11\% das 
companhias com nível de endividamento médio adotaram o valor justo, nas empresas com alto endividamento o percentual de uso do valor justo é de $11,36 \%$. Em contrapartida, nas companhias com alto nível de endividamento, $88,64 \%$ optaram por mensurar os ativos intangíveis por meio do custo histórico. Nas companhias de médio porte esse percentual é de $88,89 \%$.

Tabela 16 - Associação entre o endividamento e o método de mensuração do intangível

\begin{tabular}{|c|c|c|c|c|c|}
\hline Ativo & & Baixo Endividamento & Médio Endividamento & Alto Endividamento & Total \\
\hline \multirow{3}{*}{ Frequência } & Custo Histórico & 33 & 40 & 39 & 112 \\
\hline & Valor Justo & 7 & 5 & 5 & 17 \\
\hline & Total & 40 & 45 & 44 & 129 \\
\hline \multirow{3}{*}{ Percentual } & Custo Histórico & $82,50 \%$ & $88,89 \%$ & $88,64 \%$ & $86,82 \%$ \\
\hline & Valor Justo & $17,50 \%$ & $11,11 \%$ & $11,36 \%$ & $13,18 \%$ \\
\hline & Total & $100 \%$ & $100 \%$ & $100 \%$ & $100 \%$ \\
\hline
\end{tabular}

Fonte: Elaborado pelas autoras

Com relação às PPI, apenas uma empresa com baixo nível de endividamento optou pela mensuração de PPI por meio do valor justo, conforme pode ser observado na Tabela 17.

Tabela 17 - Associação entre o endividamento e o método de mensuração das PPI

\begin{tabular}{|c|c|c|c|c|c|}
\hline \multicolumn{2}{|c|}{ PPI } & Baixo Endividamento & Médio Endividamento & Alto Endividamento & Total \\
\hline \multirow{3}{*}{ Frequência } & Custo Histórico & 6 & 5 & 14 & 25 \\
\hline & Valor Justo & 1 & 0 & 0 & 1 \\
\hline & Total & 7 & 5 & 14 & 26 \\
\hline \multirow{3}{*}{ Percentual } & Custo Histórico & $85,71 \%$ & $100 \%$ & $100 \%$ & $96,15 \%$ \\
\hline & Valor Justo & $14,29 \%$ & $0,00 \%$ & $0,00 \%$ & $3,85 \%$ \\
\hline & Total & $100 \%$ & $100 \%$ & $100 \%$ & $100 \%$ \\
\hline
\end{tabular}

Fonte: Elaborado pelas autoras.

O Teste Qui-quadrado ( $p$-valor $=0,244$ ) não apontou associação (Tabela 17) entre a escolha do método de mensuração das PPI e o nível de endividamento das entidades. Todas as companhias com nível de endividamento médio e alto adotaram o custo histórico na mensuração das PPI. É interessante destacar que a única empresa da amostra a adotar o valor justo para a mensuração de PPI pertence ao Reino Unido, possui uma menor rentabilidade, é de pequeno porte e têm um menor nível de endividamento.

Christensen e Nikolaev (2013) também identificaram associação entre o nível de endividamento e o uso do valor justo. Para os autores, as companhias tendem a adotar o valor justo, visto que, empresas que necessitam de empréstimos, normalmente, precisam oferecer garantias para obtenção do crédito.

Após o exposto, nota-se que, na adoção inicial das IFRS, o país $\left(\mathrm{H}_{1}\right)$, o porte $\left(\mathrm{H}_{4}\right)$ e o nível de endividamento $\left(\mathrm{H}_{5}\right)$ das entidades estavam associados com a escolha do método para a mensuração de ativos não financeiros.

\section{Considerações Finais}

O presente trabalho teve por objetivo identificar os fatores que se associam com a escolha do método para a mensuração de ativos não financeiros. Para a realização da pesquisa foi selecionada uma amostra de 150 empresas, sendo 50 alemãs, 50 brasileiras e 50 pertencentes ao Reino Unido. O período em estudo foi o ano de adoção das IFRS, ou seja, 2005 para Alemanha e Reino Unido e 2010 para o Brasil. Para testar a associação entre determinados fatores que se associam com a escolha dos métodos de mensuração dos ativos não financeiros utilizou-se o Teste Qui-quadrado.

Com relação ao país de origem das companhias $\left(\mathrm{H}_{1}\right)$, os resultados apontam que o Brasil foi mais propenso a optar pelo valor justo para o ativo imobilizado e para o ativo intangível na adoção inicial das IFRS. Contudo, é pertinente destacar que isso ocorreu em virtude do uso do custo atribuído, uma vez que a mensuração subsequente do imobilizado e intangível por meio do valor justo não é permitida no Brasil. Além disso, verificou-se que o Reino Unido foi o único a ter uma entidade com PPI mensurada pelo valor justo, visto que as empresas da Alemanha e do Brasil, que compõem a amostra, optaram, exclusivamente, pelo uso do custo histórico quando se trata de PPI. Conjectura-se, assim, que esses resultados corroboram os fundamentos da Teoria Institucional e sugerem que o país em que a empresa atua está associado com a escolha do método para mensuração dos ativos não circulantes.

No que se refere à escolha do método de mensuração em entidades com distintos níveis de rentabilidade, os resultados não indicaram a existência de associação entre a rentabilidade e a escolha do método contábil $\left(\mathrm{H}_{3}\right)$. No entanto, foi possível perceber que as empresas com menor rentabilidade foram as que mais optaram pelo uso do valor justo para a mensuração dos ativos não financeiros quando comparadas com as companhias que apresentaram média e alta rentabilidade.

Quanto à relação entre o método de mensuração dos ativos não financeiros e o tamanho da empresa $\left(\mathrm{H}_{4}\right)$, foi observado que o tamanho está associado com a escolha do método de mensuração do ativo imobilizado. Percebeu-se que as empresas de médio porte foram as que mais optaram pelo uso do valor justo na mensuração do ativo imobilizado. As companhias de grande porte tiveram maior percentual de adoção do 
custo histórico para o ativo imobilizado, intangível e PPI. Ressalta-se também que apenas uma companhia de pequeno porte optou pela mensuração de suas PPI por meio do valor justo.

Com relação ao endividamento das companhias $\left(\mathrm{H}_{5}\right)$, os resultados apontam que o nível de endividamento está associado com a escolha do método de mensuração do ativo imobilizado. É relevante salientar que as companhias com maior endividamento tiveram o maior percentual de adoção do custo histórico para os ativos não financeiros. Em contrapartida, para o ativo imobilizado as companhias que possuem um nível médio de endividamento foram as que mais optaram pelo valor justo. Quanto ao ativo intangível e PPI, as empresas menos endividadas tiveram maior percentual de adoção do valor justo quando comparadas às empresas com um nível de endividamento médio e alto.

Os resultados do presente estudo suportam a ideia de que as companhias dos três países da amostra priorizaram o uso do custo histórico para a mensuração dos ativos não financeiros, corroborando os resultados de Christensen e Nikolaev (2013), visto que os autores também identificaram uma predileção das companhias pelo uso do custo histórico. Evidenciou-se que a Alemanha possui uma postura mais conservadora quando se trata do uso do valor justo na mensuração de ativos não financeiros, reforçando a ideia de que os países do grupo Europa Continental são mais conservadores. No que refere ao Brasil, pertencente ao grupo de países emergentes, verificou-se a maior adesão ao valor justo. No entanto, esse resultado deve ser avaliado com cautela porque as observações contemplaram o caso do uso do custo atribuído na adoção inicial das normas contábeis, não se podendo estimar se a escolha seria diferente num cenário em que a prática fosse permitida em anos posteriores. Contudo destaca-se que o presente estudo traz como avanço a inclusão de um país emergente na amostra, visto o reduzido número de estudos que objetivam verificar as práticas contábeis em países emergentes vis-à-vis países desenvolvidos. Quanto ao Reino Unido, percebe-se um comportamento menos conservador, quando comparado com a Alemanha, uma vez que a Alemanha não utilizou o valor justo para nenhum dos ativos não financeiros verificados.

A partir dos resultados evidenciados é permitido sugerir a influência de fatores em nível país, como sistema jurídico, e em nível empresa, como endividamento, tamanho e rentabilidade, na adoção das IFRS, o que suscita dúvidas sobre a efetividade do trabalho do IASB na harmonização das práticas contábeis mundiais, mesmo que a harmonização normativa já foi, com certo êxito, atingida.

Como limitações do estudo destaca-se a coleta de dados manual, que pelo subjetivismo inerente, pode ensejar interpretações distintas em outro estudo. Ademais, a falta de padrão na forma de apresentação das informações nas demonstrações contábeis e a possibilidade, não explicitada pelas companhias, de mensurar somente parte dos ativos de uma classe por um determinado critério também se configuram como limitação aos resultados obtidos. Assim sugere-se a necessidade de cautela na generalização dos resultados. Para pesquisas futuras sugere-se verificar as opções de mensuração dos ativos não financeiros em outros países representativos dos sistemas jurídicos, avaliando também fatores adicionais que possam determinar a opção pelo custo histórico ou valor justo. Além disso, conhecer as motivações dos preparadores das demonstrações financeiras para adotar uma opção em detrimento de outra são avanços relevantes sobre o tema.

\section{Referências}

BARTH, M. E. Global comparability in financial reporting: What, why, how, and when? China Journal of Accounting Studies, v. 1, n. 1, p. 2-12, 2013. DOI: https://doi.org/10.1080/21697221.2013.781765

BOTINHA, R. A.; LEMES, S. Comparabilidade das escolhas contábeis em propriedades para investimentos de empresas listadas na BM\&FBOVESPA e NYSE. Revista Contabilidade, Gestão e Governança, v. 20, n. 1, p. 113-132, 2017. DOI: https://doi.org/10.21714/1984-3925_2017v20n1a7

CARPENTER, V. L.; FEROZ, E. H. Institutional theory and accounting rule choice: an analysis of four US state governments' decisions to adopt generally accepted accounting principles. Accounting, Organizations and Society, v. 26, p. 565-596, 2001. DOI: https://doi.org/10.1016/S0361-3682(00)00038-6

CERQUEIRA, D.; REZENDE, A. J.; DALMÁCIO, F. Z.; SILVA, J. M. S. O impacto do reconhecimento do custo atribuído e da divulgação de impairment de ativos tangíveis e intangíveis (IFRS) sobre os preços e os retornos das ações das companhias brasileiras. Revista de Contabilidade do Mestrado em Ciências Contábeis da UERJ, v. 17, 2013. DOI: https://doi.org/10.12979/rcmccuerj.v17i3.5338

CHRISTENSEN, H.; NIKOLAEV, V. Who Uses Fair-Value Accounting for Non-Financial Assets Following IFRS Adoption? In: SSRN, 2009. DOI: 10.2139/ssrn.1265371.

CHRISTENSEN, H. B.; NIKOLAEV, V. V. Does fair value accounting for non-financial assets pass the market test? Review of Accounting Studies, v. 18, n. 3, p. 734-775, 2013. DOI:

https://doi.org/10.1007/s11142-013-9232-0 
COSTA, P. S.; LOPES, A. B. Implicações da adoção das IFRS sobre as book-tax differences: o caso do Brasil. 1. ed. Alemanha: Novas Edições Acadêmicas, 2015.

COTTER, J.; ZIMMER, I. Asset revaluations and assessment of borrowing capacity. Abacus, v. 31, n. 2, p. 136-151, 1995. DOI: https://doi.org/10.1111/j.1467-6281.1995.tb00359.x

DEMARIA, S.; DUFOUR, D. First time adoption of IFRS, fair value option, conservatism: Evidences from French listed companies. In: EAA Congress, 2007. Proceedings..., 2007

DIETRICH, J. R.; HARRIS, M. S.; MULLER, K. A. The reliability of investment property fair value estimates. Journal of Accounting and Economics, v. 30, n. 2, p. 125-158, 2000. DOI: https://doi.org/10.1016/S01654101(01)00002-7

DIMAGGIO, P. J.; POWELL, W. W. The iron cage revisited: institutional isomorphism and collective rationality in organizational fields. American Sociological Review, v. 48, n. 2, p. 147-160, 1983. DOI: $10.2307 / 2095101$

FARGHER, N.; ZHANG, J. Z. Changes in the measurement of fair value: Implications for accounting earnings. Accounting Forum. v.38, n. 3, p. 184-199, 2014. DOI:

https://doi.org/10.1016/j.accfor.2014.06.002

FÁVERO, L. P.; BELFIORE, P.; SILVA, F. D.; CHAN, B. L. Análise de dados: modelagem multivariada para tomada de decisões. Rio de Janeiro: Elsevier, 2009.

INTERNATIONAL ACCOUNTING STANDARD - IAS 16. Property plant and equipment. Londres: IASB, 2014.

INTERNATIONAL ACCOUNTING STANDARD - IAS 38. Intangible Assets. Londres: IASB, 2014.

INTERNATIONAL ACCOUNTING STANDARD - IAS 40. Investment Property. Londres: IASB, 2016.

ISA, M. A. Determinants of accounting choice of noncurrent assets at IFRS first adoption among Nigerian firms. Procedia-Social and Behavioral Sciences, v. 164, p. 378-383, 2014. DOI:

https://doi.org/10.1016/j.sbspro.2014.11.091

JUNG, B.; POURJALALI, M. H.; WEN, E.; DANIEL, S. J. The association between firm characteristics and CFO's opinions on the fair value option for non-financial assets. Advances in Accounting, incorporating Advances in International Accounting, v. 29, n. 2, pp. 255-266, 2013. DOI:

https://doi.org/10.1016/j.adiac.2013.03.002

LEUZ, C.; WÜSTEMANN, J. The role of accounting in the German financial system. In: SSRN, 2003. DOI: https://doi.org/10.2139/ssrn.427000

LEVINE, M. D.; BERENSON, M. L.; STEPHAN, D. Estatística: teoria e aplicações. Rio de Janeiro: LTC Editora, 2000.

LIBBY, R.; RENNEKAMP, K. M.; SEYBERT, N. Regulation and the interdependent roles of managers, auditors, and directors in earnings management and accounting choice. Accounting, Organizations and Society, v. 47, p. 25-42, 2015. DOI: https://doi.org/10.1016/j.aos.2015.09.003

LIN, Y. C.; PEASNELL, K. V. Fixed asset revaluation and equity depletion in the UK. Journal of Business Finance and Accounting, v. 27, n. 3-4, pp. 359-394, 2000. DOI: https://doi.org/10.1111/1468-5957.00317

MCDONOUGH, R. P.; SHAKESPEARE, C. M. Fair value measurement capabilities, disclosure, and the perceived reliability of fair value estimates: A discussion of Bhat and Ryan (2015). Accounting, Organizations and Society, v. 46, p. 96-99, 2015. DOI: https://doi.org/10.1016/j.aos.2015.05.003

NOBES, C. The survival of international differences under IFRS: towards a research agenda. Accounting and Business Research, v. 36, n. 3, p. 233-245, 2006. DOI:

https://doi.org/10.1080/00014788.2006.9730023

NOBES, C. IFRS practices and the persistence of accounting system classification. Abacus, v. 47, n. 3, p. 267-283, 2011. DOI: https://doi.org/10.1111/j.1467-6281.2011.00341.x 
SANTOS, E. S.; CALIXTO, L. Impactos do início da harmonização contábil internacional (Lei 11.638/07) nos resultados das empresas abertas. RAE - eletrônica, v. 9, n. 1, jan. /jun., 2010. DOI:

https://doi.org/10.1590/S1676-56482010000100006

SARQUIS, R. W.; LUCCAS, R.; LOURENÇO, I.; DALMACIO, F. Z. IFRS accounting systems' classification: A new emerging cluster. In: SSRN, 2014. DOI: https://doi.org/10.2139/ssrn.2374610

SCOTT, W. R. Financial Accounting Theory, 5th ed, Toronto: Pearson, 2009.

SILVA, D. M. Escolhas contábeis e características corporativas de empresas de grande porte na adoção do IFRS em duas etapas: diagnóstico e análise. 2016. Tese (Doutorado em Controladoria e Contabilidade) - Faculdade de Economia, Administração e Contabilidade de Ribeirão Preto, Universidade de São Paulo, Ribeirão Preto, 2016.

SILVA, D. M.; MARTINS, V. A.; LEMES, S. Escolhas contábeis: reflexões para a pesquisa. Revista Contemporânea de Contabilidade, v. 13, n. 29, p. 129-156, 2016. DOI: https://doi.org/10.5007/21758069.2016v13n29p129

SOUZA, F. E. A.; LEMES, S. A comparabilidade das escolhas contábeis na mensuração subsequente de ativos imobilizados, de ativos intangíveis e de propriedades para investimento em empresas da América do Sul. Revista Contabilidade \& Finanças, v. 27, n. 71, p. 169-184, 2015. DOI: https://doi.org/10.1590/1808$057 \times 201501480$

TAPLIN, R. H; YUAN, W.; BROWN, A. The use of fair value and historical cost accounting for investment properties in Chine. Australian, Accounting, Business and Finance Journal, v. 8, n.1, p. 101-113, 2014. DOI: https://doi.org/10.14453/aabfj.v8i1.6

WATTS, R. L. Accounting choice theory and market-based research in accounting. The British Accounting Review, v. 24, n. 3, p. 235-267, 1992. DOI: https://doi.org/10.1016/S0890-8389(05)80023-X

YAO, D. F.; PERCY, M.; HU, F. Fair value accounting for non-current assets and audit fees: Evidence from Australian companies. Journal of Contemporary Accounting \& Economics, v. 11, n. 1, p. 31-45, 2015. DOI: https://doi.org/10.1016/j.jcae.2014.12.003

ZEFF, S. A. Some obstacles to global financial reporting comparability and convergence at a high level of quality. The British Accounting Review, v. 39, n. 4, p. 290-302, 2007. DOI:

https://doi.org/10.1016/j.bar.2007.08.001

\section{NOTAS}

\section{AGRADECIMENTOS}

Ao Programa de Pós-graduação em Ciências Contábeis - PPGCC e à Faculdade de Ciências Contábeis - FACIC da Universidade Federal de Uberlândia

\section{CONTRIBUIÇÃO DE AUTORIA}

Concepção e elaboração do manuscrito A. F. Pinto; S. Lemes; N. S. Almeida

Coleta de dados: A. F. Pinto; N. S. Almeida

Análise de dados: A. F. Pinto; N. S. Almeida

Discussão dos resultados: A. F. Pinto; S. Lemes; N. S. Almeida

Revisão e aprovação: A. F. Pinto; S. Lemes; N. S. Almeida

\section{CONJUNTO DE DADOS DE PESQUISA}

O conjunto de dados que dá suporte aos resultados deste estudo não está disponível publicamente.

\section{FINANCIAMENTO}

Não se aplica.

CONSENTIMENTO DE USO DE IMAGEM

Não se aplica.

\section{APROVAÇÃO DE COMITÊ DE ÉTICA EM PESQUISA}

Não se aplica. 


\section{CONFLITO DE INTERESSES}

Não se aplica.

\section{LICENÇA DE USO}

Os Direitos Autorais para artigos publicados neste periódico são do autor, com direitos de primeira publicação para a Revista. Em virtude de aparecerem nesta Revista de acesso público, os artigos são de uso gratuito, com atribuições próprias, em aplicações educacionais, de exercício profissional e para gestão pública. A Revista adotou a licença Creative Commons Atribuição 4.0 Internacional - CC BY NC ND. Esta licença permite acessar, baixar (download), copiar, imprimir, compartilhar, reutilizar e distribuir os artigos desde que com a citação da fonte, atribuindo os devidos créditos de autoria. Nesses casos, nenhuma permissão é necessária por parte dos autores ou dos editores. Autores têm autorização para assumir contratos adicionais separadamente, para distribuição não-exclusiva da versão do trabalho publicada nesta revista (ex.: publicar em repositório institucional ou um capítulo de livro).

\section{PUBLISHER}

Universidade Federal de Santa Catarina. Curso de Ciências Contábeis e Programa de Pós-graduação em Contabilidade. Publicação no Portal de Periódicos UFSC. As ideias expressadas neste artigo são de responsabilidade de seus autores, não representando, necessariamente, a opinião dos editores ou da universidade.

\section{EDITORES}

Carlos Eduardo Facin Lavarda e Suliani Rover

\section{HISTÓRICO}

Recebido em: 27/03/2019 - Revisado por pares em: 20/04/2020 - Reformulado em: 30/05/2020 Recomendado para publicação em: 05/06/2020 - Publicado em: 30/06/2020 